ISBN 978-93-84468-92-7

International Conference on Issues in Education, Literature, Humanities and Social Sciences

(IELHSS-2017)

Kuala Lumpur (Malaysia) Jan. 4-5, 2017

\title{
Lived Experience of Economically Marginalized English Learners
}

\author{
Paulina Erawati Paramita \\ Academy of Foreign Language Widya Dharma (Pontianak, Indonesia)
}

\begin{abstract}
This research attempts to describe the lived experience of economically marginalized learners of English. This study employs a qualitative approach, especially the phenomenology method, which is trying to explore human lived experiences. The techniques used in this research sequentially were in-depth interview, classroom observation, and document checks. The process of the interview was also recorded. The participants consisted of three students from a Vocational School in Indonesia who experienced learning English under a low financial background. The result of this research shows that the participants are looking forward of being able to use English functionally as a language, although they are learning under economy hardship. Unfortunately, the economic conditions in their school and their family are less supportive for the learners to develop and fulfill their goals in communicative English. Later, from the researcher's interpretation on the findings, the researcher suggests the research readers in general and teachers to improve any current less beneficial conditions regarding the socioeconomic issue discussed in this thesis. This research is successfully able to build the researcher's emphatic understanding and self-reflection for better personal development. The highlight of the suggestions includes the improvement on learners' and school facilities, and the teachers' competence in delivering the English language materials and in giving instructions.
\end{abstract}

Keywords: learning, lived-experiences, low financial, facilitation, teacher's competence

\section{Introduction}

In English language learning there are many factors which affect its process. Many studies find that there are correlation between socioeconomic factors and the learning process, especially English learning in this term. Khattak et al. in Souriyavongsa (2013) states that the poor socioeconomic is one of factors that create learners to face with the use foreign language. In addition to that, Hashemi in Souriyavongsa (2013), identified that students'weakness in English language learning is due to the differences of social contexts, cultural environments. Besides, a survey into the causes of English language learning anxiety in students by Khattak, Jamshed, Ahmad, \& Baig in Souriyavongsa (2013) also found that - Students were afraid of making mistakes in the classes, failing the exams, as well as the poor socioeconomic cause of the poor performance in learning languages.

Furthermore, Bordieu (1986) states that - The notion of cultural capital initially presented itself, in the course of research, as a theoretical hypothesis which made it possible to explain the unequal scholastic achievement of children originating from the different social classes by relating academic success.l From Bordieu's explanation above, it can be concluded that the difference of economic background, as a part of factors in social classifications, can affect different result of learning in the process.

The statements show that the factor, in this term is the low socioeconomic condition of the learners, is considered to be a factor that affects the process of ELL. From those ideas, the researcher assumes that there is clear connection from financial background towards the learners 'process of learning especially English; therefore this research is made to understand how the learners with low financial background learn English. However, the 
research does not focus on the learners 'underachievement to be observed, but more to find how they get through the process of ELL under low economic condition.

Based on the explanations above, the socioeconomic condition therefore can trigger several impacts in the efficiency of English learning in many countries including Indonesia. Indonesia is considered as a country with high chances of financial interference which can be possibly experienced by the learners or institutions that are working within its educational scope.

It is clear that many factors can affect the process of English learning. In this term, the low social-economic capacity issue is taken as a factor to be focused on. Furthermore, the researcher is looking to find out how and what influences occur during the English learning process. The researcher would like to take concern on how learners from low social economic condition learn English. Furthermore, the researcher is looking to describe how learners from low financial capacity undergo the learning process. The process to be observed covers the methods of learning applied during the class activities, the facility used during the learning process, and the learners 'responses towards English learning activities inside and outside the classroom. In addition to that, the importance of doing the research on this topic is to build empathic understanding for the researcher and the research's readers, and equity towards low financial capacity learners, as well as to describe the lived-experience of economically marginalized learners of English from the observed school.

\section{Theoretical review}

\subsection{Language Learning Process}

According to Das (1988), - in the term of communication done by more than one individual, language learning is learning to $=$ conform' (adjust) to conventional systems. $\|$ Das (1988) also adds that learners do not learn language through intensive pattern practice but when they are forced to communicate or exchange messages with others. From those statements, it can be concluded that language learning process is closely associated with interactional and communicative effort rather than grammar-based learning.

\subsection{The Role of Consciousness in Language Learning}

According to van Lier (1996), consciousness can be closely associated with interpersonal concept, which originates in interaction with the world and is closely tied to sociocultural development. In addition to that, Vygotsky in van Lier (1996) defines consciousness as the objectively observable organization of behavior that is imposed on humans through participation in sociocultural practices. Through the statements above, it can be concluded that consciousness in learning, particularly language learning process, is taking an important role individually or interpersonally.

\subsection{Motivation}

Dornyei in Ellis (2008) claims that there were almost 100 studies published in this decade. The literature about motivation shows that there are several classifications of the types of motivation. Gardner (1985) as quoted by McGroarty in McKay and Hornberger (1996) defines integrative motivation as the desire to be like and interact with speakers of the target language, and instrumental motivation as the desire to learn a language in order to achieve some other goals such as academic or occupational success.

\subsection{Awareness}

Awareness and motivation are basically similar. According to Sinclair (1999), - without an explicit and conscious awareness of the processes involved in learning a language, learners will not be in a position to make informed decisions about their own learning. It means that awareness is needed by the learners to understand their position in learning and help them determine willingness to get informed from what they get during the process of learning. 


\subsection{Learning Interaction}

Rivers (1987) stated that through interaction, students can increase their language store as they listen to read authentic linguistic material', or even the output of their fellow students in discussions, joint problem-solving tasks, or dialogue journals. In interaction, students can use all of their possession of the language, all they have learned or absorbed in real life exchanges, where expressing their real meaning is important to them. Interaction is important word for language teachers and learners in creating good communication in teaching and learning activity inside and outside classroom.

\subsection{Low Financial Capacity}

According to data in Central Statistics Board of Indonesian Government (1999), in measuring absolute poverty, a basic need approach is being adopted. An individual is considered to be poor if and only if his/her income level is below defined poverty line. Poverty line is basically a minimum standard income required by an individual to fulfill his/her basic necessity for both food and non-food (Central Statistics Board of Indonesian Government, 1999).

\section{Research Method}

This study intends to describe the lived-experience of low financial capacity learners' in learning English in vocational school. This research is a phenomenology research which employs qualitative approach. According to Patton (2002) phenomenology focuses on exploring how human beings make sense of experience and transform experience into consciousness. Creswell (2012) says that a phenomenology study describes the meaning for several individuals of their lived experiences of a concept or a phenomenon. In other words, it can be said that in this term, lived experience is associated with concept based on the actual events that happen in individual's life. Van Manen (1990) says that phenomenology describes how one orients to lived experience. Participants for the study are students of the Putratama Vocational School Bantul who experience learning English under low financial capacity and Environments. The techniques used in this research were in depth-interview, classroom observation, and document checks. In this research the researcher will describe the participants' lived experience in the form of narratives.

\section{Finding and Discussion}

This section presents the main data of the research based on the interview. The data includes the result of the interview with the three participants. They are Tiwi as the first participant, Rizka as the second participant, and Apri as the third participant.

\subsection{The Participants' Lived Experiences on Language Learning Process}

By reflecting on the students' lived experiences in learning English at the vocational school, it is found that they are still far from being communicative. The indicator can be seen from Tiwi's admission that she only speaks English occasionally in her classroom, uses English in facebook, and discusses using English with the teacher more often than with her classmates. She also added that she will be embarrassed to expose her English speaking in public because of bad pronunciation and the lack of vocabularies. In addition to that Tiwi told the researcher that she is usually taught English using Bahasa Indonesia more often than using English. Furthermore, Tiwi is usually taught using grammar based method more often than the communicative one. Rizka isSimilar with Tiwi, The last participant is Apri. He seldom speaks English in class because he is afraid of making mistakes. Apri also said that he rarely discuss using English in the class because his friends are usually less serious to do that. From the interview result, Apri admitted that grammar based method dominates the teaching learning activities in his class.

With the absence of the communicative based activities during the participants' ${ }^{6}$ English language learning process, it means that any participants' goals related with the communication and speaking ability, in this term is can be found in Tiwi's and Apri's interview, will not be smoothly succeed in their school. 


\subsection{The Participants' Lived Experiences on Consciousness}

Tiwi and Rizka have good consciousness to be active in responding teacher's question which also means that Tiwi and Rizka can be active enough to be involved in more communicative English teaching and learning activities. Meanwhile, Rizka and Apri do not have enough consciousness to pay attention to teacher's explanation Tiwi, Rizka and Apri realize that in order to understand deeper on her learning process, they need to make any kind of highlight to help her remembering the information or understanding some missing information. Later, Tiwi and Rizka also said that the teacher usually points passive students in the class. They also think that teacher should pick more passive students to give them opportunity to practice. From this situation they are conscious that the teacher points certain student in class to help them get speaking opportunity in the learning activity. This situation also appears in Rizka's and Apri's case which means that the participants are conscious about the importance of being active in the English learning process.

From the three participants' interview results the researcher finds that Rizka and Apri do not acquire enough consciousness in paying attention to teachers' explanation while Tiwi is found to be good enough at it. The three participants' similar good consciousness is can be indicated from the way they deal with the information highlighting technique during the English learning process which means that they can somehow manage the missing information from their learning.

\subsection{The Participants' Lived Experiences on Motivation}

Tiwi is in overall dominantly has integrative motivation in her learning because her goal is to be able to speak English like native speaker. In other hand, prefers to get good score instead of being able to speak English. Furthermore, the researcher finds that Apri does not have dominant tendency on integrative or instrumental motivation. All of them want to get good job. Regarding the results related with the instrumental and integrated motivation, the participants lived experiences in practicing communicative English show the indication whether the participants have been in the proper track or not to fulfill either their instrumental or integrated motivation. In this case, Tiwi and Apri are found not being in the proper track since they experience less communicative learning activities regarding with their goal. Meanwhile, Rizka is the only participant who can fulfill her motivation, in this term is the instrumental motivation.

\subsection{The Participants' Lived Experiences on Awareness}

Tiwi's interview result shows the lack of awareness which can be indicated from her lack of preparation on the upcoming lessons, her willingness to do homeworks at home, and her seldomness in learning English outside the school time and environment. In Rizka's case, Rizka is having lack on her preparation on the upcoming lessons since she admitted that although she read the materials at home she will still have difficulties on understand them. In addition to that Rizka also seldom learns English outside the school time and environment which indicates the lack of awareness. Meanwhile, Rizka is aware enough toward her homework. In Apri's case, the lack of awareness can be indicated from his seldomness in preparing upcoming lessons and the lack of learning English outside the school time and environment. Similar with Rizka, Apri has good awareness to deal with his homework.

In addition to that, the researcher finds that Tiwi, Rizka and Apri can manage to conduct self-learning through movies and lyrics outside of the school hour. It shows that they all have awareness to learn by themselves using fun and interesting media.

\subsection{The Participants' Lived Experiences on Learning Interaction}

Tiwi, Rizka and Apri do not have individual difference in their experience regarding with the learning interaction. All of them share the same experience that they have lack on interactions in the language learning process. The learning interaction activities by all of the three participants are still far from enough for communicative language learning and teaching activity. It can be indicated from the findings that the grammarbased method is still become the primary activity that is conducted in almost every lesson of the three participants' English learning process and also the participants' lack of opportunity and experience in speaking 
using English. In addition to that, the lack of interactions can also be found from the fact that individual activities during the English learning process is still dominates over the group works and assignments.

\subsection{The Participants' Lived Experiences on Low Financial Factor}

From the interview, the researcher finds that all of the three participants have not had enough pocket money from their parents. The researcher assumes that the amount of their daily pocket money will not be able to support them for unexpected spending in the term of learning. Furthermore it is indicated that the economic condition make them have some kind of limitation and effect on the participants' mood to study. Tiwi, Rizka, and Apri also have less support from their parents to study at home. In addition to that, Tiwi and Rizka have to be distracted to study at home because she has to do housekeeping. Fortunately, the economic problem had not had a significant effect on the three participants' health problem in school. Different with Tiwi and Rizka, Apri does not have significant distraction from his family since he is free from any housekeeping responsibility. But, still Apri has problem in his mood to study at home for example because of having few amount of pocket money. The researcher also finds that Rizka admitted that she does not have real problems with dictionary or books since she can borrow it from her sister. However, the dictionary is still far from proper

The researcher later also found that the economic problem is not only happens in the participants ' family but also his school which leads to lack of facilitation like adequate library supply. There is even no language laboratory to support their English language learning process.

\subsection{The Participants' Lived Experiences on English Acquisition}

From the motivation factor aspect, Tiwi and Apri are found to have more dominant integrative motivation compared to Rizka. The findings are shown from the Tiwi's and Apri's tendency to learn English as communicative means and from Rizka's tendency to use English as instrument to support her English examinations. From the three participants' interview result, the researcher finds that communicative English teaching and learning activity has not become the primary approach in their lived experience. It can be indicated from the little amount of interaction and discussion experienced by all of them inside and outside the class. The teacher even still dominantly prefers grammar-based method rather than communicative interactive activity during the English teaching and learning process.

\section{Conclusion}

Based on the research question: What is the lived-experience of learners with low financial capacity in the English learning process of vocational school like? This research has described the participants' lived experiences and then the researcher can draw the essence of English learning process in learners of vocational school with low financial capacity. After the analysis the researcher can conclude some conclusions. There are seven conclusions of this research as mentioned below: First, English learning process in SMK Putratama Bantul is still using less communicative approach, in which it will not be able to fulfill any learners' goal to master communicative English as the nature of language. Second, learners who have good consciousness to learn English in communicative way will be difficult to develop their learning. Third, learners with dominant integrative motivation to learn English will not be able to fulfill communicative English goal since they tend to encounter lack in their communicative teaching and learning activity. Fourth, the three participants show their interest in establishing English self-learning through entertainments such as movies and lyrics. Fifth, the learners in SMK Putratama Bantul also experience very limited amount of interactions during English language teaching and learning activities. Sixth, the low economy hardship of the learners' family gives impact on the learners' motivation to study at school, or the way they are being facilitated by the family or the school. Seventh, the learners with low financial capacity will be difficult or even impossible to achieve the the goal of English acquisition referring to functional and communicative English as a language, since the English teacher still mostly prefer grammar-based and textbook method in the process. 


\section{References}

[1] Bourdieu, P. (1986). The Forms of Capital. J. Richardson (Ed.) Handbook of Theory and Research for the Sociology of Education. New York: Greenwood.

[2] Central Statistics Board of Indonesian Government. Poverty Measurement the case of Indonesia. (1999). Retrieved on June 21, 2012, from http://www.unescap.org/stat/meet/povstat/pov7 ido.pdf.

[3] Cresswell, J. W. (2012). Educational Research. Thousand Oaks: SAGE.

[4] Das, B. K. (1988). Materials for Language Learning and Teaching. Singapore: SEAMEO Regional Language Centre.

[5] Ellis, Rod. (2008). The Study of Second Language Acquisition. New York: Oxford University Press.

[6] Gardner, R. C. (1985). Social Psychology and Second Language Learning: The Role of Attitudes and Motivation. London: Edward Arnold.

[7] McKay, S. L. and Hornberger, N. H. (1996). Sociolinguistics and Language Teaching. Cambridge: Cambridge University Press.

[8] Patton, M. Q. (2002). Qualitative research and Evaluation Methods. Los Angeles: Sage Publications, Inc.

[9] Rivers, Wilga M. (1987) Interactive Language Teaching. Cambridge: Cambridge University Press.

[10] Sinclair, B., McGrath, I., \& Lamb, T. (1999). Learner Autonomy, Teacher Autonomy. Harlow: Future Directions, Longman.

[11] Souriyavongsa, T. (2013). Factors Causes Students Low English LanguageLearning: A Case Study in the National University of Laos. International Journal of English Language Education, 1(1) [Online]. Retrieved on November 21, 2013 ,

from http://www.academia.edu/2442165/Factors_Causes_Students_Low_English_Language_Learning_A_Case_Study_in_the_ National_University_of_Laos.

[12] van Lier, L. (1996). Interaction in the Language Curriculum: Awareness, Autonomy \& Authenticity. Harlow: Pearson Education, Ltd. 